\title{
Influence of Brexit on Economy and Revenue
}

\author{
Shen Zhaozhang, Bai Yijun \\ College of Economy of Ji'nan University, Guangzhou 510632
}

Key words: Brexit, economy, revenue

\begin{abstract}
Abstrac. Brexit has given rise to the sharp reaction in the financial market, substantial depreciation of the pounds, and the lowering of the British sovereign credit by the major global credit rating agencies. Aiming at the "Black Swan Event" of Brexit, this paper applies comparative analysis, induction, and deduction to comprehensively analyze the latest status inside British, EU's attitude towards the British, and current economic situation. It discusses the influence of different positioning on the European Union relationship on the British economy and revenue. This paper holds that, the Brexit will make British achieve more independent finance and tax sovereignty; the British revenue policy will not be restrained by the law of the European Union; the adjustment of the domestic policies will have greater flexibility in future; meanwhile, it will have different impact on the foreign-related taxation policies of Britain.
\end{abstract}

Britain and EU are the important global systematic economic entities approved by IMF. Therefore, Brexit not only may have profound impact on the British economy, but also will bring about certain impact on the European economy and global economy. From the viewpoint of the real economy, the impact of Brexit on the British economy and European Union economy will pass onto other economic entities through the trade, investment, and other channels. From the viewpoint of the financial system, Brexit makes the international financial institutes that enter into the financial market of EU through Britain have to make choice again, which will bring about certain influence on the business operation of the international financial institutions. Under the recovery of the current global economy, any sign of trouble may arouses market fluctuation.

Recently, four institutes, such as Department of Finance, OCED, Confederation of British Industry, Economic Indication Research Center of The London School of Economics and Political Science, etc., have made assessment on the economic consequence of Brexit. Four reports adopt different economic models and policy analysis frameworks, but the achieved conclusion is quite similar: once Brexit happens, the economic loss may reach 1\%-9\% of the British GDP. The report conclusion of each institution is within this scope. To provide perceptual intuition, OECD uses the saying of Brexit Tax, so as to present that this action is the "tax" exerted on every British citizens. Different from common tax payment, Brexit tax does not provide various public facilities and social welfare; instead, it is only loss. Such loss is represented in various forms. At present, more than 2 million British citizens live, study and work in other member countries of EU. Besides, Britain has attracted around $48 \%$ foreign direct investment from EU countries. According to the prediction from OECD, Britain after Brexit will face lots of capital outflow in future 3 to 5 years, while it will seriously threaten the common accounts occupying more than 7\% GDP. The Department of Finance predicted the long-term influence of Brexit, and it put forward that the decreasing of the trade and investment would lead to the gliding of the production efficiency, and then threatens the national economy and the people's livelihood. In fact, the decreasing confidence on the British economy has already brought about negative influence. The latest data released by Office of National Statistics displays that, the GDP growth rate of Britain in the last season is the lowest in recent four years; however, in the financial market, since last autumn, the exchange rate between pounds and Euro and dollar has been depreciated. The increasing uncertainty of the economic prospect not only affects the investment, but also exerts negative impact on the trade, employment, migration, etc. The major economic influence is reflected in the following aspects:

Firstly, Brexit will influence the trade and investment relationship between Britain and European Union. Since from the establishment of EU, Britain has gradually established close trade and 
investment relationship with many European countries. After Brexit, the trade and investment agreement previously signed between Britain and EU countries will become invalid. If Britain strives for the EU market access, it should carry out EU trade and investment agreement negotiation with EU countries again, which will have negative impact on the trade relationship between Britain and EU. According to statistics, the export to EU accounts for around 1/2 of the British export, which means Brexit will greatly affect the British foreign trade in short term. Meanwhile, Breixt will make Britain lose the trade preference policy it enjoys as an EU country. The decreasing of export will have direct impact on the employment of companies n Britain, and it will affect some foreign investment companies, as these companies that invest in Britain may focus on the status of Britain in EU.

Secondly, Brexit will bring impact on the international finance center status of London. London is always the important financial center in the world. The confirmation of its international financial center status is from the free finance trade environment, and it is also the favorable condition for the Britain to enter into the EU market. For instance, after studying the site selection decision of 147 finance institutions from 2006 to 2012, British finance service company finds out that, over 2/5 finance enterprises regard selecting London for entering into EU market as the main reason. Therefore, after Brexit, the superiority of London will not exist, and its international finance center status will be weakened.

Thirdly, Brexit will restrict the pounds, and then arouse the turmoil of the global finance market. After Brexit, the value of the pounds to dollar decreased by $10 \%$, which touched the lowest level since 1985. The dollar to Yen increased by 6\%. FTSE 100 Index futures reduced by 6.1\%, America S\&P index futures reduced by 3.6\%, ICIW 224 Index futures reduced by $6.7 \%$, and Seoul index reduced to $4.1 \%$, which was the sharpest decreasing from 2011. With the enhancement of the hedge emotion, the cash gold expanded by $4 \%$. At the same time of great depreciation of pounds, the British sovereign credit level was lowered by the Standard \& Poor's, Fitch Group, Moody's, and other global credit rating institutions. Under the situation that the current global currency exchange rate fluctuates greatly and the international finance market suffers great turmoil, the decreasing and fluctuation of the pound exchange rate enhanced the risk of the British economy, and increased the difficulty of the currency policy operation.

At present, although Brexit becomes a fact, it takes long time to completely leave EU. According to Lisbon Agreement in 2009, although Britain decides Brexit, it needs to take around 2 years to completely get rid of EU. During this period, it will initiate a series of negotiation, and redefine the relationship between the future Britain and other EU members. Therefore, what impact of Brexit on Britain, EU and even global economy will be defined based on the new relationship between involved parties.

Before Brexit negotiation is not ended, legally Britain does not need to change the revenue policy due to the referendum on the Brexit. The trade between Britain and EU can be operated as usual, but it does not mean there is no actual influence. Because the negative expectation and actual negative result from Brexit on the British economy will influence the revenue policy of the British government.

Recently, Brexit has aroused great concern over the world. The finance market has made great response. Pound has depreciated greatly. Besides, British sovereign rating has been lowered by main global credit rating institutions. The predicted negative influence from Brexit before referendum is emerging. What impact from Brexit on the revenue?

On June $24^{\text {th }}$, HMRC released No. 42 “Tariff Information File” CIP. Aiming at the background of Britain's referendum on Brexit, it emphasized the referendum would not have immediate impact on the commodity and personnel flow between Britain and EU. Before "retreat from EU" in Clause 50 of Lisbon Agreement is initiated, Britain stopped participating in EU's decision, and negotiated with EU about Brexit. Before the negotiation is completed and Brexit is confirmed, Britain is still applicable to EU law; while Brexit negotiation takes at least 2 years.

Cameron, the Prime Minister of the United Kingdom, indicated that, only after Britain confirmed the new Prime Minister in October, 2016, then the government led by the new minister can 
negotiate with EU about the Brexit. Before that, Clause 50 of Lisbon Agreement would not be initiated. That is to say, in recent 2 years at least, before Brexit negotiation is not ended, legally Britain does not need to change the revenue policy due to the referendum on Brexit. The trade between Britain and EU can be operated as usual, without any law barriers.

However, recently, although there is no legal influence, it does not mean there is no actual influence, as the negative expectation and actual negative impact of Brexit on British economy will influence the revenue policy of the British government. In fact, before referendum on Brexit, Osborne, Chancellor of the Exchequer, indicated that, to cope with the impact of Brexit on the British economy, the government would establish an emergent budget proposal with the scale of around 30 billion pounds to stabilize the public finance through increasing revenue and reducing expenditure. The increment is equal to the tax increasing, with the purpose of increasing 2\%-3\% individual income tax, wine and fuel oil consumption tax. After the referendum is over, Osborne said in the first public speech on June $27^{\text {th }}$, the result of referendum on Brexit would influence the British economy and public finance, and the government should take countermeasures. On June $28^{\text {th }}$, Osborne accepted BBC's interviewing, and indicated that, the tax increasing would be an inevitable choice. However, in face of the economy weakness after referendum on July $3^{\text {rd }}$, Osborne accepted the interviewing of Financial Times, and presented that the income tax rate of the company was reduced from $20 \%$ to $15 \%$, which aroused great concern in public.

However, no matter to improve the individual income tax and consumption tax, or to reduce the income tax of the company, it is necessary to implement them through complex legislative procedure. In fact, the income tax rate of the British companies is lowered in recent 20 years. In the budget proposal of 2016 and 2017, it is predicted that the income tax rate of the British companies will be reduced to $17 \%$ till 2020 . Nowadays, in face of many uncertainties resulting from Brexit, the effect of showing the "pie" that reducing the tax rate to $15 \%$ is doubted. The biggest problem in UK is the uncertainty, including the uncertainty from the British government towards the measures. However, one point can be confirmed. If the result of Brexit is the same as what happens at present: depreciation of pounds, the lowering of the sovereignty credit rating, negative economy, then the loss will finally be owed to the taxpayers. The degree of paying the bill depends on the negative influence degree of Brexit. However, it greatly depends on the Brexit negation result between Britain and EU.

The result of Brexit negotiation between Britain and EU is not confirmed till now. Although Britain finally departs from EU, there is still uncertainty in the negotiation result. What new partnership Britain and EU can achieve? To become an EEA member like Norway? Or to become a standard EEA member like Switzerland? Or become a trade partner that has close relationship with EU, like Canada? Or become a common trade partner under WTO framework?

Obviously, after Brexit, the different relationship between Britain and EU will have different impact on British economy and revenue. From different perspective of view, Brexit will make Britain achieve more independent finance and taxation sovereignty. The revenue policy of Britain will no longer be restricted by the law of EU. The adjustment of the future domestic policies will have greater flexibility. However, at the same time, it will have different influence on foreign-related taxation of Britain.

The first one is tariff policy. Brexit means Britain departs from the uniform market and tariff alliance of EU. The goods and labor cannot be freely imported and exported among EU members. What tariff policy will be adopted depends on the positioning of the trade relationship between Britain and EU, and the specifically achieved trading condition during the Brexit negotiation. Anyway, the trade will not be as convenient as before. For the enterprises, although the tariff factor is not taken into account, the cost for the transnational trade will be increased.

The second one is domestic indirect tax policy. The coordination degree of the EU consumption tax is relatively high. The added-value tax policy is restricted by various EU directives. However, the tax policy shows the requirements of EU through changing to domestic law. Therefore, legally speaking, if Brexit happens, the domestic added-value tax and consumption tax policy will be no longer restricted by EU law. Whether the current policy should be adjusted and how to adjust is the 
revenue sovereignty determined by Britain. Some people are worried that, the value-added tax law and consumption law of Britain (including other member countries) are rooted in law of EU, and affected by EU, including the influence from European Court of Justice on revenue case judgment. It is worthy of focus after Brexit. However, the author holds that it completely depends on the will and procedure of the domestic related tax law modification. If no willing to modify or inconvenient to modify in short term, it is feasible to implement it according to current regulation. With regard to the cross-border between Britain and EU members, due to the "customs boundary" change as mentioned above, it will affect the added-value tax and consumption tax management of import/export trade. Especially, it will greatly affect the small supplier that is engaged in the online trading of the digital products.

The reason is that, for the online trading of the digital products by means of B2C, EU has started to implement "The Principle of The Place of Consumption" from Jan. $1^{\text {st }}$, 2015. It requires the overseas suppliers to conduct added-value tax registration in EU. However, to provide convenience for the internal management of EU, EU has developed a "Mini-One-Stop Shop Online Application System" (MOSS system for short). The enterprises from the EU member countries can conveniently conduct added-value registration and declaration through any of domestic portals. Obviously, after Britain quits from EU, it means the British taxpayers cannot use this system; instead, they need to conduct the registration and pay tax like other companies that do not come from EU countries, according to the requirements of EU. The more outstanding point is that, the changes of the added-value tax system of online trading of digital products in 2015 make the small taxpayers that cannot reach the standard of added-value tax registration (e.g. 8,300 pounds of the annual sales volume in Britain) realize the obligation of paying added-value tax in the sales countries. Therefore, Britain carries out special exemption policy, and allows the taxpayers that cannot reach the registration standard to enjoy the tax exemption. They, they do not need to pay the added-value tax through MOSS system. However, after Brexit happens, this privilege for the small taxpayers cannot be continued.

The third one is income tax policy, including corporate income tax and individual income tax. The degree of the direct tax adjusted by EU is not higher than that of the indirect tax. In recent years, the coordination of the corporate income tax pushed by EU still has many obstacles, including the objection from Britain. Therefore, comparatively speaking, the independence of the income tax policy is stronger, and it is slightly restricted by the EU law. However, the issue about the duplicate taxation and anti-tax avoidance for the transnational corporations, EU has made great coordination. For instance, the directive of parent-subsidiary corporation, European saving directive, collection and management directive, latest approved anti-tax avoidance directive have greatly impact on the income tax system of the member countries and the transnational companies. Therefore, after Britain quits from EU, how to implement joint stock tax exemption, interest pre-deferred income tax policy and the confirmation of the taxpayer identity of the "Clause about Limitations on Interest" in tax treaty may bring about inconvenience to the British companies, so it is necessary to have new bilateral arrangement for associating.

In summary, the impact of Brexit on the economy and revenue has lots of uncertainties. What impact of Brexit on British, EU and even global economy can be defined based on the new relationship between involved parties.

\section{References}

[1] WangYanan.Brexit Promotes Great Increasing of Renminbi[EB/LO], http://finance.huanqiu.com/roll/2016-07/9118931.html

[2] Zhang Wei. Brexit's Impact on Transnational Corporation [EB/LO], http://news.esnai.com/2016/0701/136165.shtml

[3] Chen Xiao. Brexit May Influence Chinese Enterprises’ Merging and Investing in Britain

[EB/LO],http:/www.ccpit.org/Contents/Channel_4126/2016/0628/663525/content_663525.htm 